\title{
Eruptions of the Ethical Baroque
}

Steven Shankman

University of Oregon

Renaissance perspective constructs objective reality from the viewpoint of a sovereign subject. The border protecting the sovereignty of this subject is sometimes crossed, in the Baroque, by means of the subject's sudden awareness of the humanity of the other person and of our inescapable responsibility for that unique and irreplaceable other. With examples from music, painting, and literature, I discuss what I call "eruptions of the ethical Baroque." These eruptions trouble the serenity of the arts and haunt us: one such eruption reveals, to the Christian warriorcrusader Tancredi, the face of the apparently Muslim female warrior Clorinda, in Monteverdi's Combattimento (1624); another reveals, to Abraham - in Rembrandt's 1635 painting of "The Sacrifice of Isaac" - the face of his son Isaac and then suddenly interrupts what appeared to have been an imminent murder; another forces us to encounter, in Shakespeare's disruptively sober prose, Shylock's Jewish eyes; yet another, in Paul Celan's arguably modern Baroque poem Tenebrae, interrupts - but too late, tragically — the profoundly enchanting pathos of François Couperin's high Baroque choral masterpiece, Leçons de ténèbres, which inspired Celan's poem.

What, exactly, is the Baroque? Modern theorists—such as Gilles Deleuze, with his notion of the fold-have discussed its significance and pondered the question of whether or not there is such a phenomenon as the Baroque.' The word Baroque was not used by any of the artists and thinkers of the historical period-the seventeenth and early eighteenth centuries in Europe-sometimes referred to by this term. It was first used as a stylistic term in 1855 (by Jacob Burkhardt in the Cicerone and by William Luebke in his Geschichte der Architektur). Even its etymology is unclear. It is possibly derived from the Portuguese barroco, meaning "a rough or imperfectly shaped pearl," or from the word baroco, a mnemonic term invented for the fourth mode of the second figure of formal logic, a term that conveys a sense of surprise and shock that seems, in fact, to defy logic. Both of these possible derivations convey something that, one still feels, goes to the heart of our sense of the Baroque. There is something disruptive about the Baroque. Classicism gives us proportion and decorum, the Baroque disproportion and the disruption of decorum, as the art historian Heinrich Wölfflin (d. 1945) so pregnantly suggested in his book Renaissance and Baroque, first published in 1888.

One of the things that is disrupted in the Baroque is the stability, the autonomy of the subject. When we think of Renaissance Humanism, we think of Pico's famous 
"Oration on the Dignity of Man" (1486). You are, Pico imagines God saying to man, "constrained by no limits, in accordance with your own free will... We have set thee at the world's center that you may from there more easily observe whatever is in the world." 2 And we think of perspective in Renaissance painting, the world as object perceived by a sovereign subject, man or woman. In the Baroque, this sovereignty of the subject is sometimes disrupted by the Other, by the subject's sudden awareness of the humanity of the other person, and of that subject's inescapable responsibility for this unique and irreplaceable Other. For this special issue on political theology in the Baroque era, I will focus on how certain Baroque works of art call the very project of political theology into question.

\section{Tasso's Gerusalemme Liberata and Monteverdi's Combattimento}

The Baroque, as I just mentioned, disrupts the sovereignty of the Renaissance subject. The Ethical Baroque disrupts, as well, what the political philosopher Carl Schmitt claims to be the very essence of politics: the distinction between friend and enemy, a distinction, according to Schmitt, that has nothing to do with "good and evil in the moral sphere." ${ }^{3}$ What happens to the persuasiveness of this distinction when the enemy is your friend, even your lover? Let me explore this possibility by making reference to a musical example from Claudio Monteverdi, who is considered, in musicology, as composing at the beginning of the Baroque period. I shall discuss the passage that concludes Monteverdi's Combattimento di Tancredi e Clorinda, a madrigal that was staged in Venice in 1624, eleven years after the composer moved to Venice to become maestro di cappella at San Marco. The Combattimento is a setting of some stanzas from Tasso's epic poem of the Counter-Reformation, the Gerusalemme liberata (1575). We should recall here that, for the great art historian Heinrich Wölfflin, Tasso's Jerusalem Delivered was exemplary of the Baroque, as opposed to Ariosto's Orlando Furioso, which Wölfflin associated with the Renaissance. ${ }^{4}$

Tasso's Jerusalem Delivered, as musicologist David Schulenberg writes, "was a romanticised poetic account of the First Crusade (1095-99), during which Jerusalem and other parts of the Holy Land were seized from their Arab Muslim rulers by Western Roman Catholic nobles. In the scenes set by Monteverdi, one of the Western knights, 
Tancredi, is in pursuit of Clorinda, a Muslim warrior. Unbeknownst to Tancredi, Clorinda is a woman in disguise; moreover, he has previously been in love with her... The second encounter is fatal to Clorinda...; as she dies they recognize one another. In that moment, Clorinda accepts Tancredi's love and is converted to Christianity; she asks him to baptize her, which he does with water from a nearby stream." ${ }^{5}$ Tasso's poem, at least on the surface, is the Catholic Counter-Reformation poem par excellence. The intended Christian triumphalist message of Tasso's verse is clear enough, but the poet complicates and even undermines this triumphalism with his articulation of an extraordinary empathy for the vanquished Clorinda.

In Monteverdi's setting, the musical focus is not on the possible reunion of the lovers in some hypothetical afterlife. The focus is, rather, clearly on Clorinda's death, on the void felt by Tancredi in the death - at first imminent, and then absolutely realizedof the woman he loves and whom he unwittingly kills in battle. Clorinda, an Ethiopian and an apparently Muslim woman whose identity has yet to be revealed, has just asked Tancredi to seek water from a nearby spring to baptize her as a Christian before she dies:

A little way off in a cranny of the mountain a tiny streamlet had its murmuring source. There he ran and filled his helmet in the spring, and sorrowing returned to the noble and reverend rite. He felt his hand trembling while it freed and revealed the face as yet unknown. He saw it. He knew it. And remained without voice or motion. Alas the sight! alas the recognition! [Ahi vista! ahi conoscenza!]

He did not die outright [Non morì già:] $]^{6}$; rather he summoned up for the moment all his powers and set them to guard his heart; and repressing his grief he bent his efforts to giving her life with water whom with the sword he killed. While he released the sound of the holy words, she was with joy transfigured, and smiled: and through the act of her joyful and living death, she seemed to say: "Heaven is opening; I depart in peace.", Here is the conclusion of Monteverdi's Combattimento and the words from Tasso's text that the composer has set to music: 
EXaMgus 11.1 Ending of $n$ combattimento di Tancredi e Clorinda

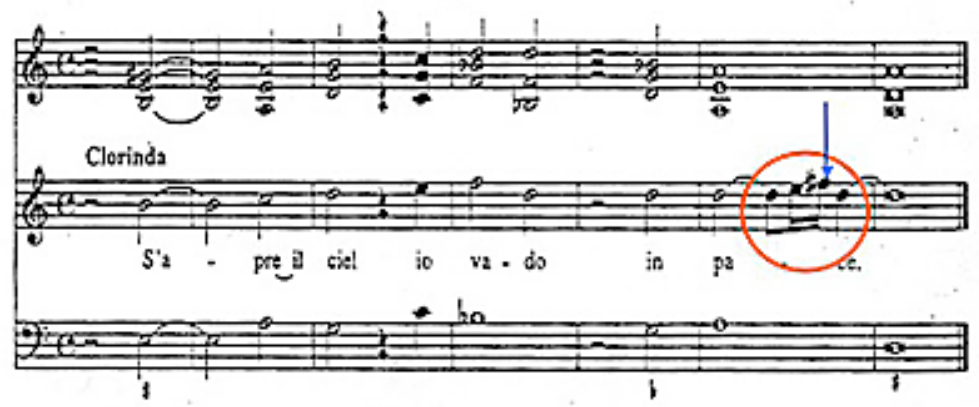

Figure I: Ending of II combattimento di Tancredi e Clorinda

[Audio Example I: Combattimento Finale]

Ahi vista! ahi conoscenza!

Non morì già, ché sue virtuti accolse

tutte in quel punto, e in guardia al cor le mise,

e premendo il suo affanno, a dar si volse

vita con l'acqua a chi co'l ferro uccise.

mentre egli il suon de' sacri detti sciolse,

colei di gioia trasmutossi, e rise;

e in atto di morir lieta e vivace,

dir parea: "S’apre il ciel; io vado in pace.

After the word "parea" ("seemed”), Monteverdi's annotations read: "this last note is bowed [so as to] die away [questa ultimata nota va in arcata morendo]." Clorinda's Islamic otherness has been assimilated into the dominant religion of an early seventeenthcentury Venice that was still proudly conscious of the Christian defeat of the Muslim Turks at the Battle of Lepanto in I57I.

For all the overt Christian triumphalism of Tasso's verse, Monteverdi's setting evoked compassion in his audience of Venetian nobility for the vanquished former Muslim of Tasso's poem. As Silke Leopold informs us, the "type of cultivated entertainment" represented by this particular madrigal "required a happy ending." 8 The audience was not quite prepared for the sad ending of the Combattimento. Monteverdi himself comments that those attending the performance in the palace of Girolamo Mocenigo (the Hotel Danieli in today's Venice) one evening during the carnevale in 1624 "were so moved by the emotion of compassion (dal' affeto di compassione) that they 
almost shed tears." True to what Monteverdi describes as his seconda pratica, in which the music is at the service of the poetic text, the composer brings out-and further deepens-the emotional complexities of Tasso's verse. The Other-the apparently Muslim enemy on the battlefield-is baptized as a Christian just before she dies, it is true, but any simple-minded Christian triumphalism is counterbalanced and even overwhelmed by a pathos for the vanquished and of a love irretrievably lost. Moreover, there is no indication, in the parts of the Gerusalemme liberata excerpted by Monteverdi, that Clorinda had in fact been born a Christian, as Tasso describes to his readers. In the Combattimento, she appears to be a Muslim, pure and simple, before her conversion.

A sense of violated otherness haunts Monteverdi's setting. The words and the music evoke an otherness that seems to exceed what the words and music represent. There is a sense of irresolution-Baroque irresolution-at the end of this piece. The Combattimento is remarkable for its series of stark contrasts in mood. As Eric T. Chafe observes, Monteverdi was fond of using the key of $d$ minor "for the greatest flat/sharp juxtapositions and disparities." 10 The piece appears to be ending in this key of $\mathrm{d}$ minor, but with Clorinda's expectation of rising into heaven "in peace" (in pace), her soprano voice ends with a shift from the darkness of $d$ minor to the light of $D$ major, the key in which the Combattimento begins. We expect the penultimate note on which she sings her final word (pace) to be an $F$, in a progression of a half-step from $E$ to $F$, which would preserve the key of $d$ minor, but the progression of another half-step from $E$ to $F$ sharp [see blue arrow pointing downwards in Figure I] accomplishes a shift from the key of $d$ minor to the key of $D$ major. The penultimate note of $F$ sharp, though announcing an officially triumphal shift to D major, nevertheless creates-with its unanticipated and haunting reach of an extra half step-a kind of dissonance or ambiguity. We feel precariously suspended, a suspension typical of Monteverdi, whose dissonances outraged more conventional musical minds like that of Giovanni Maria Artusi, and whose music as a whole is itself suspended between Renaissance modality and a later, more settled system of musical tonality. With Clorinda dead and her soprano voice departed, it is the spare instruments that bring us back again, somberly and almost silently, to the final tonic chord.

There are discussions about heaven, in Tasso, following this passage. Clorinda, in 
Tancredi's dream, appears in heaven and looks forward to Tancredi's eventually joining her there. But in Monteverdi's madrigal, Tasso's text ends before this scene. Without the certain promise of an afterlife, the martial violence of which Clorinda is the victim is far less palatable, the death of the other far more tragic. But Tasso's arguably Baroque text, even without Monteverdi's music, is haunted by the occluded other. As David Quint remarks:

The dream [of Clorinda appearing in heaven, in a later passage of the poem] comforts Tancredi, but in the celebrated episode of the enchanted forest that follows in the next canto, he is once again overcome by his guilt before the demonic simulacrum of Clorinda trapped in the bark of one of the forest's trees... Clorinda is not so easily put to rest. Tancredi's reaction suggests the bad conscience of Tasso's epic, a chink in its ideological armor... [T] here is no hiding the punitive violence of Clorinda's death-all the more naked and sadistically charged because of Tancredi's love for the woman he unwittingly kills. Tancredi is the author of this violence, which seems to exceed containment by the poem's politico-religious ideology; as a stand-in for the author Tasso, he at least casts a measure of doubt on the capacity of that ideology to resolve its own inner contradictions. ${ }^{\prime \prime}$

This exceeding of containment by ideology, or by politics, is an example of the troubling eruption of what I am calling the Ethical Baroque. In my understanding of the Ethical Baroque, which is inspired by the work of Levinas, politics comes after ethics and often-perhaps even always - betrays ethics. Levinas insists on the primacy of the ethical relation, of the face-to-face. But my responsibility to the Other in the face-toface relationship is not the last word, for there is also the third party ("le tiers"), and with the appearance of the third party comes society, law, and the state, i.e. the realm of politics. The subject is responsible for these other others as well, and this always poses the possibility, in the context of politics, of a certain betrayal of the face-to-face. ${ }^{12}$ The strict maintenance of politics, at the expense of the ethics, makes transcendence before the face of the other an impossibility. Politics without ethics, for Levinas, is totalitarianism. 
It is not only politics or ideology that is disrupted by this instance of the eruption of Ethical Baroque. Theology - the very concept of theology-is disrupted as well. Christian theology triumphs in this passage in Monteverdi and Tasso, but at the expense of life, at the expense of the life of the Other. Theological language, i.e. theo-logy, can, paradoxically, protect the subject who is speaking it from risking the possibility of the transcendence that, for Levinas, goes to the very core of what he considers to be true religiosity, which consists in a coring out [dénucléation] or a hollowing out of the ego by its concern for, its obsession with, the Other. ${ }^{13}$ As Levinas remarks, in a startling formulation, "theological language destroys the religious situation of transcendence." Levinas goes on to say, "Language about God rings false or becomes a myth, that is, can never be taken literally." ${ }^{4}$ What triumphs in this passage in Monteverdi and Tasso is what Walter Benjamin, in his essay "Critique of Violence," refers to as mythic as opposed to divine violence, which Benjamin associates with the God of the Hebrew Bible. Mythic violence, for Benjamin, "is bloody power over mere life for its own sake; divine violence is pure power over all life for the sake of the living [emphasis mine]."15

\section{Walter Benjamin, Rembrandt, Shakespeare}

Walter Benjamin theorized brilliantly_if often elusively-about the nature of the elusive concept of the Baroque in his early and seminal work, The Origin of German Tragic Drama, completed in 1925. Benjamin's subject was the German Baroque Trauerspiel, the “mourning play," from the era of the Thirty Years War (1618-1648), a religious conflict between Catholics and Protestants. The Baroque Trauerspiel, in Susan Handelman's formulation, "is a secularized form of medieval mystery play wherein history is no longer the story of redemption and where there is no longer any fulfilling eschatology." 16

Baroque allegory, according to Benjamin, does not deliver its promised salvific message. In terms of ethics, though, Baroque allegory is preferable, for Benjamin, to classicism and romanticism, for classical and romantic works of art-with their seamless unity of form and content-enchant us and thus cause us to forget our responsibilities to others. We enter into an eternal present when we experience classical and romantic works of art. Allegory, on the other hand, makes us aware of time, of diachrony (i.e. of change occurring over and through time). Its signifiers do not mean in and of 
themselves. They rather point us in a certain direction. We must wait, in time, before what they point to is revealed, even if that revelation is frustrated, denied. Thus the baroque Trauerspiel, through allegory, breaks the spell of classical art, since in the Baroque we are not meant to be totally engrossed by the representation itself at the mimetic level. Baroque allegory then fails to deliver, however, on the redemptive message to which the allegory is pointing. The attempt to articulate a seamless connection between political and theological sovereignty is, according to Benjamin, undone by the baroque Trauerspiel itself. We are thus left with the ruins of an allegory which point to no redeeming truth, fragments that, however, awaken our sense of the catastrophe of history that we can only resist by assuming the responsibility to make remake our society in the image of justice.

Benjamin's messianism, his call to ethics and to justice, is implicit in his book on the baroque Trauerspiel (written in 1925). In his remarks on the work of Sigmund von Birken (I626-I68I), for example, Benjamin observes that "The mystical instant $[\mathrm{Nu}]$ becomes the 'now' [Jetzt] of contemporary actuality; the symbolic becomes distorted into the allegorical." ${ }^{17}$ It is only later, in his reflections On the Concept of History (1940), that the messianic implications of the "now" [Jetzt] articulated in The Origin of German Tragic Drama become fully explicit through Benjamin's notion of Jetztzeit ("now-time”). In these late reflections, Benjamin insists that the historian who "proceeds from this" now [Jetzt] "ceases to tell the sequence of events like the beads of a rosary. He grasps the constellation into which his own era has entered, along with a very specific earlier one. Thus, he establishes a conception of the present as now-time [Jetztzeit] shot through with splinters of messianic time." ${ }^{\prime 18}$ What I am calling the Ethical Baroque thus eschews both a thoroughly enchanting and amoral classicism, on the one hand; and it eschews, as well, the reduction of the emotional and moral complexities of what it represents to an allegedly salvific allegorical meaning.

Let me now offer two examples of eruptions of the Ethical Baroque, one from painting and the other from literature.

Rembrandt's painting The Sacrifice of Isaac (1635) hangs in the Hermitage in St. Petersburg, Russia. In Genesis 22, God orders Abraham to take his only legitimate son, 


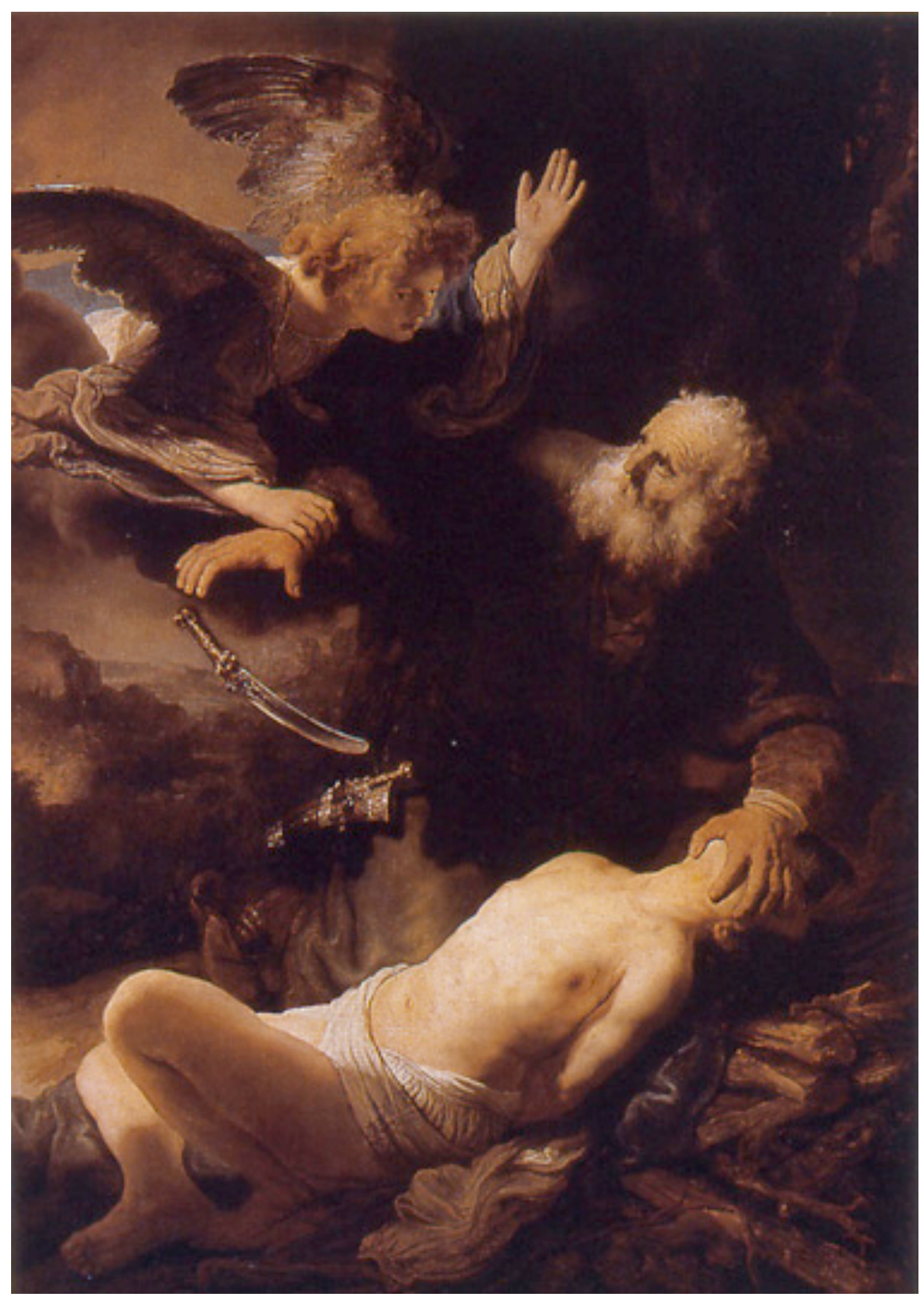

Isaac, to the top of Mt. Moriah and to offer him there as a sacrifice to God. Abraham obeys and sets out on a three-day journey. When he nears the appointed place, he commands his two young servants to stay behind, and he gathers wood for the sacrifice, taking Isaac with him. Abraham builds the altar of sacrifice with the wood he had gathered. He binds Isaac's hands and feet, places Isaac on top of the pile of wood, and he 
then raises his arm to execute God's command. The painting depicts the moment that follows from Genesis 22, specifically verses 10-12:

Avraham stretched out his hand,

he took the knife to slay his son.

But YHWH's messenger called to him from Heaven and said:

Avraham! Avraham!

He said:

Here I am.

He said:

Do not stretch out your hand against the lad, do not do anything to him. ${ }^{19}$

Rembrandt's painting dramatically depicts a moment of interruption epitomized by the knife that hangs suspended in the air, a baroque gesture that we do not find in

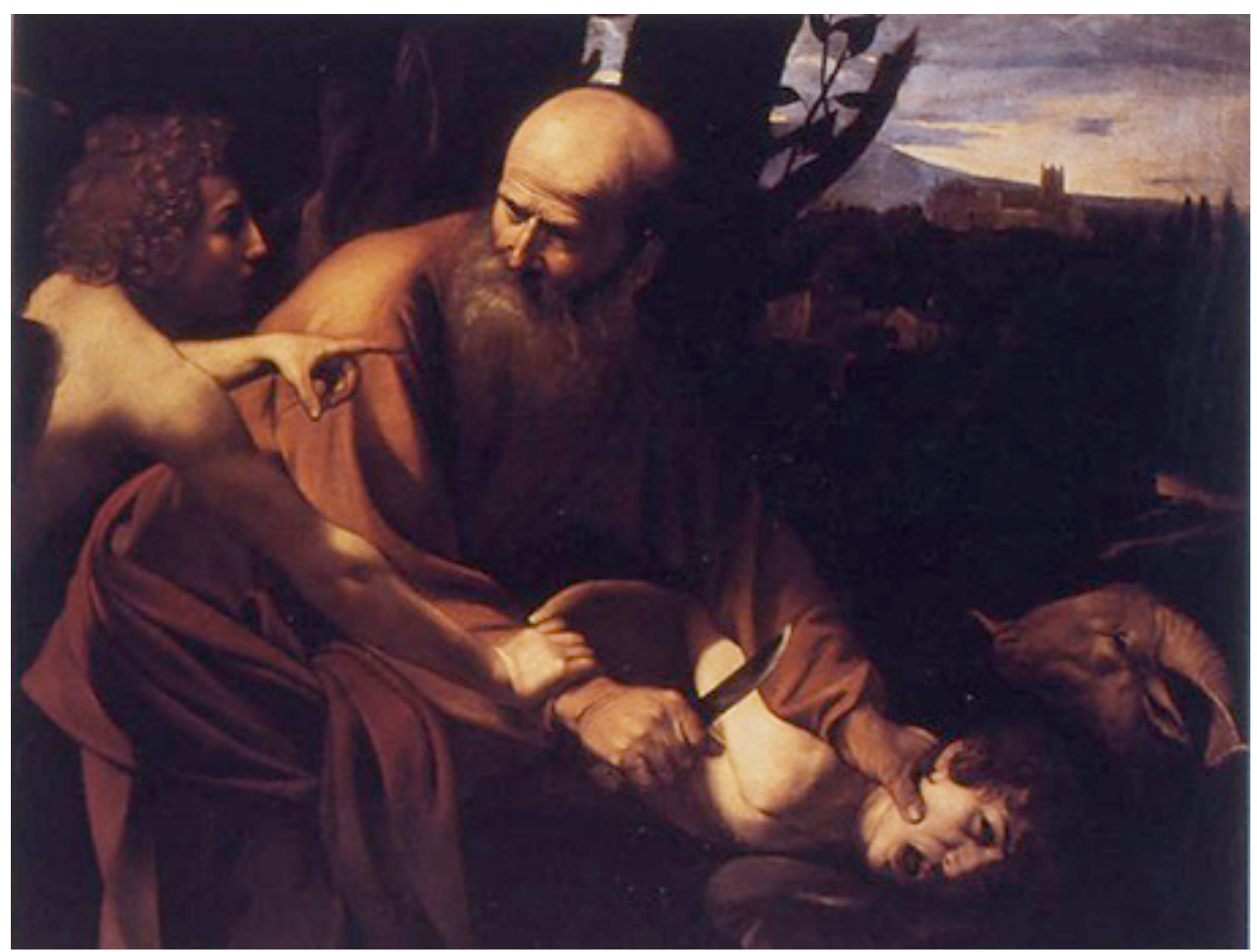

earlier pictorial depictions by Caravaggio in his The Sacrifice of Isaac (c. 1603) or by Rembrandt's teacher, Pieter Lastman. ${ }^{20}$ In both the Caravaggio and in Lastman's painting 


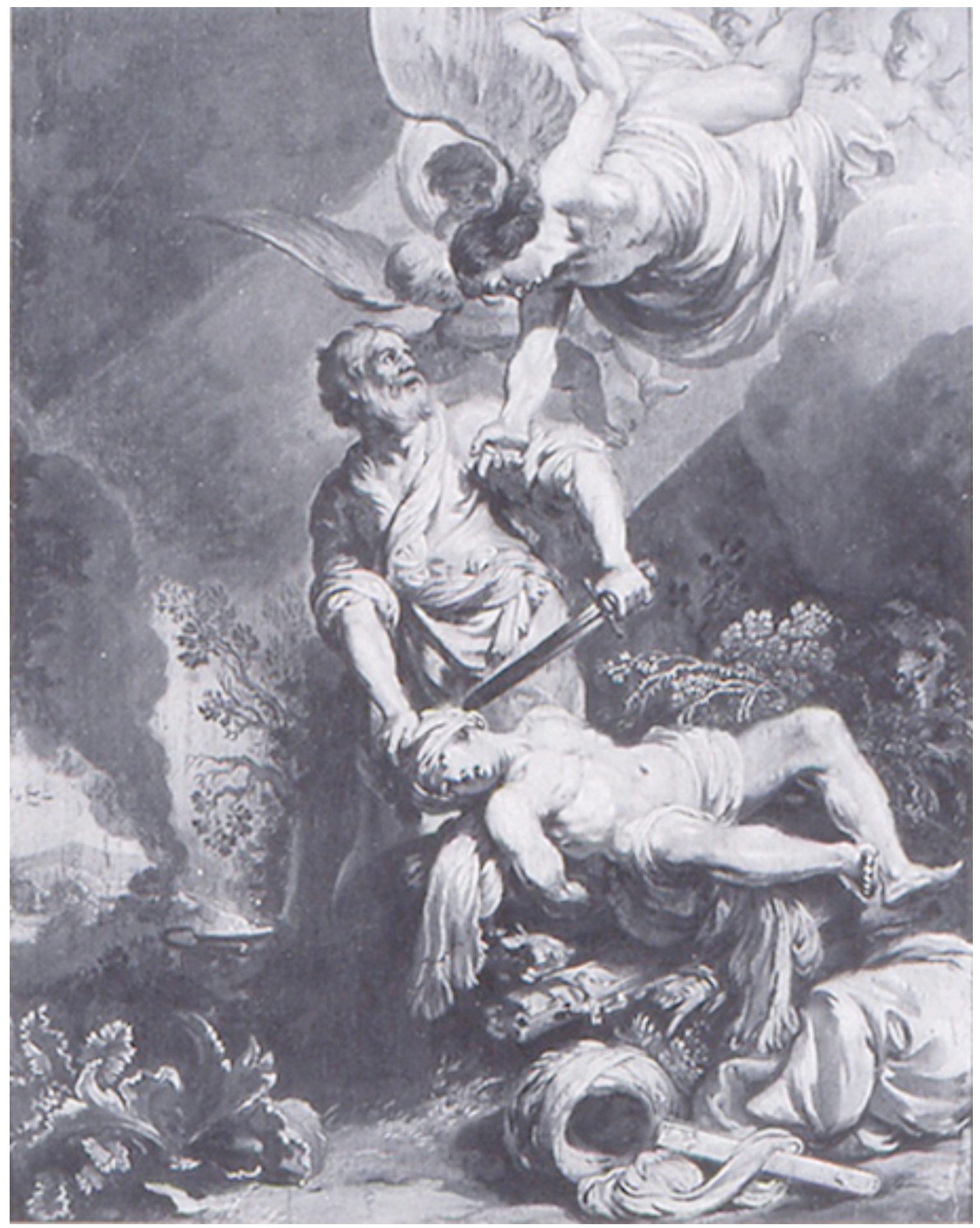

The Sacrifice of Isaac (c. 16/2), which Rembrandt knew, the knife remains firmly in Abraham's hand, whereas in the Rembrandt canvas it hangs in mid-air, having been dropped by Abraham, whose right arm the angel has seized, thus interrupting the apparently imminent slaughter. Violence, figured by the suspended knife, is thus dramatically interrupted in Rembrandt's powerful image, painted in the 1630s, at 
precisely the moment when Rembrandt was proving himself to be a "virtuoso of interruption."21

Rembrandt's 1635 painting of The Sacrifice of Isaac is true to the biblical text, which tells of how the messenger of God dramatically interrupts the imminent action with that form of the negative imperative ("al ["do not"] plus the imperative) that, in Hebrew, is especially reserved for expressing immediately pressing, specific commands: "do not stretch out (tishlach-'al) your hand"; "[and] do not do ( $v^{e}$ 'al-ta'as) anything to him." ${ }^{22}$ At this stage in his career, Rembrandt was interested in rendering the dramatic, human aspect of biblical stories. His paintings from this period were very faithful to the biblical texts that inspired his visual renderings.

In Rembrandt's painting, Abraham has covered Isaac's entire face with his left hand, suggesting at least two things. First, the father cannot bear to have the son he loves, his only legitimate son, actually witness his own father raising and lowering the knife that will enter his young and tender flesh and end his life. For Abraham to allow Isaac to witness the killing, despite the divine source of the command, no doubt filled Abraham with shame, as well as horror. Second, Abraham apparently cannot kill his son so long as he sees his son's face. Indeed, in the account of the threatened sacrifice in the Qur'an, Abraham (Ibrahim, in Arabic), in order to fulfill God's command, lays his son down prostrate on his forehead (liljabeeni 37.103). ${ }^{23}$ The implication here is that if Abraham were to look directly at his son's face, he would not be able to kill him. In his commentary on this passage, al-Tabari (839-923) elucidates the significance of Abraham's placing his son face down. According to al-Tabari, who cites a number of authorities, the son-it is unclear, in the Qur'anic account, whether this son is Ishmael or Isaac ${ }^{24}$ —remarks to his father: "When you lay me down to sacrifice me, turn me with my face down; do not lay me on my side, for I fear that if you look at my face pity will overcome you and hold you back from carrying out God's command." 25 The face, in its vulnerability —as Emmanuel Levinas is fond of remarking—speaks, and it says, "thou shalt not kill."26

The angel is looking directly at Isaac's covered_or, as Simon Schama perceptively observes, smothered_face. ${ }^{27}$ Abraham, who has avoided looking at Isaac's face, now looks directly at the face of the angel, who almost dreamily gazes straight 
ahead, neither at Abraham nor at Isaac. Who is this angel, this messenger of God who is the subject of Abraham's sudden attention and towards whose gentle face the eyes of the patriarch are abruptly turned? And what is the significance of the interruption? I hope it is not too bold to suggest that the angel or messenger (mal'akh) of God is the face of the Other - in this case the face of Isaac — suddenly commanding Abraham not to kill him. ${ }^{28}$ In Rembrandt's painting, the angel seems to be roughly the same age as Isaac, and his nose bears a marked similarity to Abraham's, making it appear as if he is in fact Abraham's son. As Levinas insists, "the face speaks." ${ }^{29}$ God reveals himself only by the trace He leaves behind in the face of the Other. ${ }^{30}$ The face of the Other, for Levinas, is not really seen, is not experienced as part of the order of the visible. It is rather "heard," as Abraham suddenly hears the voice of the angel speaking to him.

Rembrandt's painting represents this moment of interruption, which is captured not only in the sudden appearance of the angel and in Abraham's suspended knife, but also in the "anguished face" of Abraham who, as Simon Schama finely remarks, has "the look of a madman unexpectedly paroled from hell." ${ }^{31}$ If the viewer looks carefully and at close range at the Rembrandt canvas, tears of compassion can be seen to be trickling down Abraham's face. In Caravaggio's rather cruel rendering, ${ }^{32}$ Abraham seems grimly determined to slay his son and almost annoyed by the angel's sudden interference. The viewer of the Caravaggio painting is struck more by Isaac's vivid expression of absolute terror than by any sense of relief evident in the face of Abraham. Rembrandt's painting, in contrast to Caravaggio's, is a dramatic example of what I am calling an eruption of the Ethical Baroque. Abraham, hearing the voice of the messenger of God who is the face of the Other, experiences a transcendence of his own ego in the direction of ethics, as he responds to and takes responsibility for the Other whose face says "thou shalt not kill."

The shadow of allegory is present in Rembrandt's 1635 painting of "The Sacrifice of Isaac," it is true. The quality of Isaac's flesh perhaps recalls a contemporary Rembrandt painting of Christ descending from the cross. But "The Sacrifice of Isaac," as 


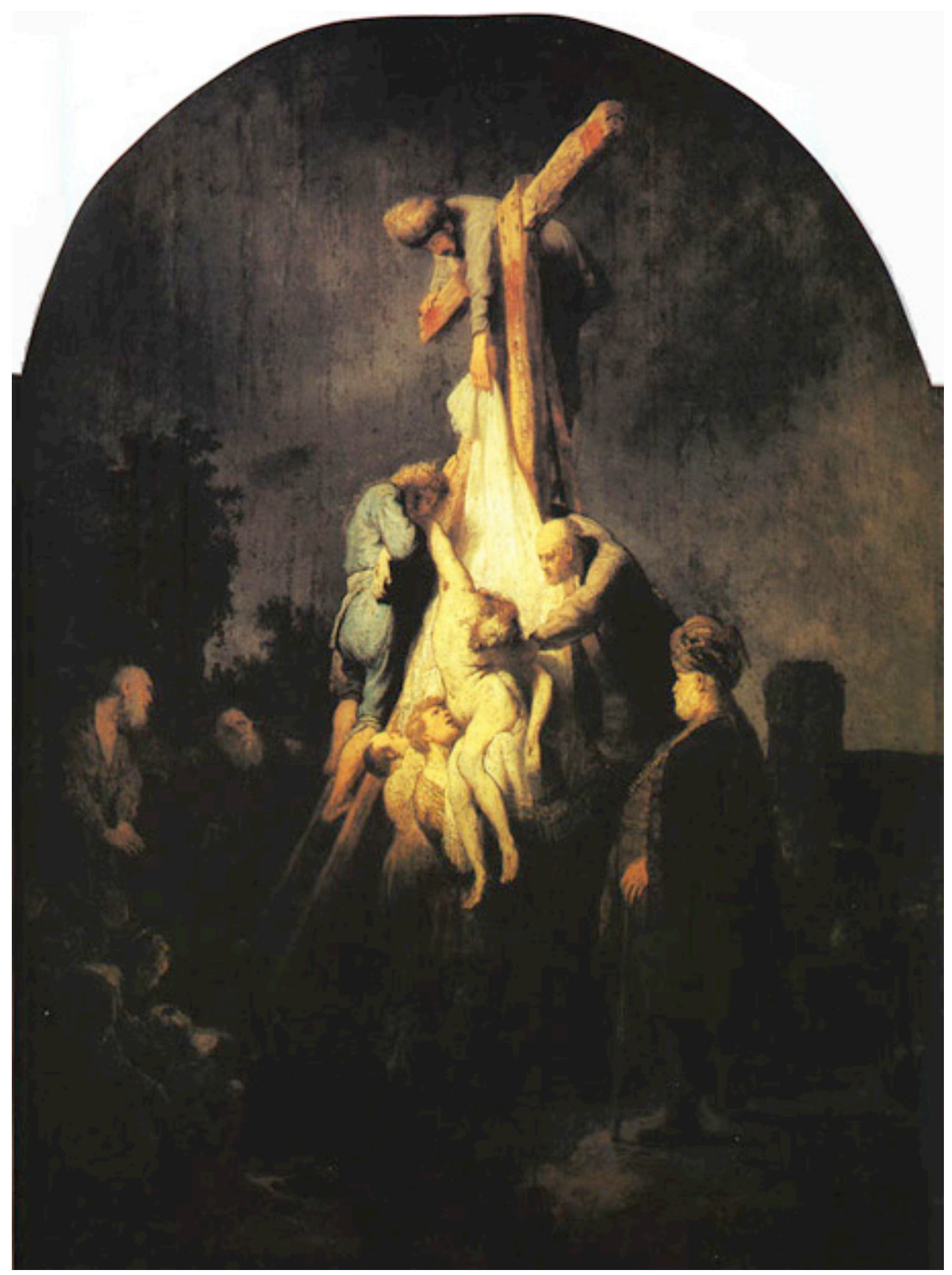

I have been arguing, gives us a vivid scene from the Hebrew Bible. It is not a sacrifice of the otherness, of the alterity of the text of the Hebrew Bible, at the altar of Christian supercessionism. Just as Monteverdi's madrigal and Tasso's poetic text are haunted by 
the occluded face (la fronte [GL 12.67. 5] of Clorinda) of the Other, so here Rembrandt's painting is haunted by the occluded face of Isaac, who appears as the face of the messenger of God.

Shakespeare's Merchant of Venice (I596/I597) was written twenty years after Tasso's Jerusalem Delivered. The Romantically inclined literary critics of Benjamin's day saw Shakespeare as the great master of naturalism. Benjamin, however, reads Shakespeare in the light_-or darkness — of the German Baroque Trauerspiel. Benjamin insists on our seeing how the art of Shakespeare's time was steeped in allegory. Benjamin writes, "in Shakespeare allegory reaches much deeper than the metaphorical forms where Goethe noticed it: 'Shakespeare is rich in wonderful figures of speech, which arise from personified concepts and which would not be at all suitable nowadays, but which are entirely in place in his work because in his day all art was dominated by allegory...." The "Sturm und Drang" movement, as well as German Romanticism, according to Benjamin, "had eyes only for the elemental aspect of his work, not the allegorical." 33

For Benjamin, Shakespearean drama is tied both to the mimetic, or naturalistic, to what Benjamin calls the "elemental," and to the allegorical. Benjamin continues, "what is characteristic of Shakespeare is precisely that both aspects are equally essential. Every elemental utterance of the creature acquires significance from its allegorical existence, and everything allegorical acquires emphasis from the elemental aspect of the world of the senses." 34

Hence, according to Benjamin, there is a tension between allegory and symbol in Shakespeare. In The Merchant of Venice, Shylock possesses, in part, an allegorical existence. $\mathrm{He}$ is an allegory representing the allegedly Jewish letter of the law, the old law, what Christians have traditionally referred to as the Old Testament. And yet Shylock is alive, he is human. He is vividly elemental, wishing to break free of the conceptual patterns that had rendered Jews as mere allegories, as literalist letters pointing to the Christian spirit, mere prefigurations of Christian truth with no otherness, no alterity of their own. 
As an example of an eruption of the Ethical Baroque, where Shylock's elemental humanity bursts free of its allegorical container, consider the moment in the play when Shylock asks his famous question "Hath not a Jew eyes?"

Salerio has just asked Shylock why he bears such ill will towards the merchant of Venice, Antonio (III. i. 50-69). Shylock responds:

He hath disgraced me, and hinder'd me half a million, laughed at my losses, mocked at my gains, scorned my nation, thwarted my bargains, cooled my friends, heated mine enemies_and what's his reason? I am a Jew. Hath not a Jew eyes? Hath not a Jew hands, organs, dimensions, senses, affections, passions? - fed with the same food, hurt with the same weapons, subject to the same diseases, healed by the same means, warmed and cooled by the same winter and summer as a Christian is? If you prick us, do we not bleed? If you tickle us, do we not laugh? If you poison us, do we not die? ? $^{35}$

We might well view Shylock's remark "Hath not a Jew eyes?" as the flickering instant in the play when the possibility of the equivalent humanity of Christian and Jew is explicitly raised by Shakespeare, an insight that, one senses, lies at the very heart of the drama, despite its often apparently overt anti-Semitism.

In a relatively early essay entitled "Reality and its Shadow" (1948), Emmanuel Levinas sees Shakespeare as one of the sources of modern literature's awareness of "the fundamental insufficiency of artistic idolatry." 36 Note that, for Levinas, modernity begins with the Baroque period-i.e. with the late sixteenth and early seventeenth centuries. Levinas associates artistic idolatry with poetry, and prose with conversation, with the opening inspired by the face of the other. He writes in Totality and Infinity:

To poetic activity... in a dionysiac mode... is opposed the language that at each instant dispels the charm of rhythm.... Addressing the other ["le discours"] is rupture..., [a] breaking of rhythm, which enraptures and transports the interlocutors-prose. ${ }^{37}$

It is perhaps no coincidence that the one moment of potential transcendence in The Merchant of Venice occurs in prose. Shylock has, in Levinas' terms, been "thematized" (or essentialized) as a Jew, and such relentless thematization and allegorization has stunted 
and perverted his humanity, which nonetheless can still be glimpsed in his face, his eyes, which are now demanding to be seen not as allegory but - to evoke Benjamin's termas element. Shakespeare's transition to prose from his vintage pentameter line gets him as close as he can, in a representation, to signifying the elemental, the human. With the phrase "Hath not a Jew eyes?", the Ethical Baroque erupts, in prose, and breaks the Dionysiac spell created by the Shakespearean pentameter.

\section{Baroque Modernity: Couperin's Leçons de ténèbres and Celan's}

\section{Tenebrae}

Are eruptions of the Ethical Baroque limited to what is conventionally referred to as the Baroque period-to the late $16^{\text {th }}$ through the early $18^{\text {th }}$ centuries of European culture? There are those who, like Christine Buci-Glucksmann and Mieke Bal, have argued that the aesthetics of modernity are essentially baroque. ${ }^{38}$ Is there a modern Baroque? Might Paul Celan's later poems be described as instances of the modern Baroque, especially if we understand Baroque art as a site of what I have been referring to as the eruption of ethics, of what Levinas calls the humanism of the Other (l'humanisme de l'autre homme)?

Let us turn to one of Celan's poems, Tenebrae, a poem he composed in 1957 and that was inspired by a piece of Baroque music - a piece not from the disruptive $17^{\text {th }}$ Century but from the more classicizing high Baroque of the $18^{\text {th }}$ Century. My argument is that Celan's poem disrupts and redirects the pathos we feel as a result of the artistic spell cast by Couperin's extraordinarily moving, and yet densely lacquered, late baroque work, the Leçons de ténèbres.

The poet first drafted his poem Tenebrae in Paris in March 1957 after he had heard a performance of the extraordinarily moving Leçons de ténèbres of François Couperin (1668-1733), who composed the work sometime between 17/3 and 1719 to accompany the Office of the Tenebrae during the Catholic Holy Week. The text, ascribed by Jewish and Christian tradition to Jeremiah, is a passionate lament on the fall of Jerusalem (586 B.C.E.) and an exhortation to repentance and to meditation. The first verse (in the Vulgate), following the "Incipit" reads: Quomodo sedet sola civitas plena populo ("How doth the city sit solitary that was full of people". 39 
[Audio Example 2: "Incipit"]

[Audio Example 3: “Aleph”]

The solitude of the devastated city points forward, typologically, to the solitude of Jesus, whose disciples have parted from him, one by one, just before his arrest and subsequent death by crucifixion. The liturgical practice of dark [tenebrae] masses such as this one expresses, ritually, this abandonment of Jesus. At the beginning of these lamentations, thirteen candles are burning. Twelve of these candles are then extinguished, one by one, symbolizing the twelve disciplines who left Jesus, one after another. At the conclusion, there is only one lit candle left, and this symbolizes the abandoned Jesus and the belief that the only road to salvation is through Him.

The Lamentations of Jeremiah, when read typologically, is thus cut loose, in Couperin's piece, from the historical situation to which the Hebrew text refers, which is the destruction of the first Temple in Jerusalem by the Babylonians in 586 BCE. The Lamentations of Jeremiah is the text read and meditated upon during the liturgical service held on Tisha B'av, the ninth day of the month of $A v$, the most mournful day of the Jewish calendar. Tisha B'av traditionally commemorates the destruction of the first and second Temples, both of which were destroyed — remarkably — on the same day of the Jewish calendar, the ninth of Av: the first Temple in $586 \mathrm{BCE}$, as I have just mentioned, and the second by the Romans in $70 \mathrm{CE}$. One of the catastrophes remembered today on Tisha $B^{\prime} A v$ is the most catastrophic of catastrophes for the Jewish people, the Shoah or Holocaust. Hence, it is fitting that Celan, in Tenebrae, meditates upon the Shoah and, in effect, returns the Lamentations of Jeremiah to a Jewish context. But more than this: Celan suggests how allegorical thinking itself-how typology - can be a source of violence against the Other.

Allegory can be cruel, especially typological allegory. Traditional Christian typology stipulates that the text of the Hebrew Bible is valuable - is indeed invaluableinsofar as it points forward to the New Testament. The Hebrew Bible, including the Lamentations of Jeremiah, is assimilated into the new dispensation. The danger here is that the Hebrew text will be denied its alterity, its otherness, and Jews are denied theirs. Here we have the doctrine of supercessionism, i.e. that idea that, as 
the great modern philosopher Hegel held, Christianity has turned Judaism into a historical necessity that is, at the same time, a contemporary anachronism, indeed a scandal. This officially changed with Vatican II (1965), but Celan wrote Tenebrae (1957) nearly a decade before Vatican II.

After attending a performance of Couperin's moving work with his wife Gisèle, who was raised a Catholic, Celan wrote Tenebrae:

[Audio Example 4: Celan, Tenebrae]

Near we are, Lord, near and graspable.

Grasped already, Lord, clawed into each other, as if each of our bodies were your body, Lord.

Pray, Lord, pray to us, we are near.

Windblown we went there, went there to bend down to the trough and the crater.

Went to the watering-hole, Lord.

It was blood, it was

what you shed, Lord.

It shone. 
It cast your image into our eyes, Lord.

Eyes and mouth stand so open and void, Lord.

We have drunk, Lord.

The blood and the image that was in the blood, Lord.

Pray, Lord,

We are near. ${ }^{40}$

Nah sind wir, Herr,

nahe und greifbar.

Gegriffen schon, Herr,

ineinander verkrallt, als wär

der Leib eines jeden von

uns dein Leib, Herr.

Bete, Herr,

bete zu uns,

wir sind nah.

Windschief gingen wir hin,

gingen wir hin, uns zu bücken

nach Mulde und Maar.

Zur Tränke gingen wir, Herr.

Es war Blut, es war,

was du vergossen, Herr.

Es glänzte. 
Es warf uns dein Bild in die Augen, Herr.

Augen und Mund stehn so offen und leer, Herr.

Wir haben getrunken, Herr.

Das Blut und das Bild, das im Blut war, Herr.

Bete, Herr.

Wir sind nah.

What "shone," what appeared in the "image" (Bild) of the blood shed by Christ in Celan's poem is, in part, the widely held conception that the Jews were responsible for Christ's Crucifixion. In the Judaic conception (Genesis I:26), man is made in God's image (__ zelem). Man thus shares in God's divinity. The persecution of the Jews and of Christ are, on the one hand, reflections of each other: the Jews participate in communion, they drink Christ's blood in so far that they, like the Jewish Jesus, are persecuted and murdered. The Jews have thus continually drunk the blood of Christ (Wir haben getrunken, Herr, I. 19). They have been forced to drink-and thereby to consume and to annihilate - the "image" (Bild is the common translation, in the German Bible, of the Hebrew__zelem of Genesis I. 26-27; ${ }^{41}$ this is how Buber and Rosenzweig translate the Hebrew word) of the divine that is supposedly contained in their own faces, which they see reflected in the blood they are about to drink before they die. The Jews have drunk the blood, and they have also drunk "the image that was in the blood (das Bild, das im Blut war, I. 20)," which I take to mean the conception, the idea-that has "shone" for over two millennia, and that is at the root of Christian antiSemitism - that the Jews are responsible for Christ's death. This idea that has shone, that has glistened, has, in its icy conceptuality, been the source of hatred and of murderous violence against Jews.

Christ's blood shone, and "Es warf uns dein Bild in die Augen, Herr (It cast your image into our eyes, Lord)." The Lord to whom this line is addressed is both God and Jesus. Too often, when a Christian looks into the eyes of a Jew, Celan suggests, he sees not the image of God, but "dein Bild, Herr (your image, Lord)," that is, the image of 
Christ crucified by the Jews. The Jews are not perceived as fully human, as made in God's image. Rather, they are reduced to the status of animals drinking from a trough. The Catholic Encyclopedia of 1912 reports that the religious service of Tenebrae terminates "with the close of the day in order to signify the setting of the sun of justice and the darkness of the Jewish people who knew not our lord and condemned him to the gibbet of the cross." 42 Hath not a Jew eyes? Apparently not, if, when a Christian looks into the eyes of a Jew, he sees not a human being but an image of the darkness of disbelief and of responsibility for the Crucifixion of Jesus. In Tenebrae, Celan recovers the Jewish faces that the persecutors of the Jews-blinded by the image (das Bild) they had of the Jews_-refused to see: Augen und Mund stehn so offen und leer, Herr ("Eyes and mouth stand so open and void, Lord").

Here we have a powerful description of the faces of the Jewish prisoners that we recall from those horrifying photographs of stacks of emaciated corpses piled on one top of the other, often with their eyes and mouths opened wide, vacant, as if pleading for help that, were it miraculously to come, would come too late. In Celan's recording of the poem, we clearly hear the vulnerable openness of that last syllable, that last word, which echoes the first word of the poem: "nah."

These are the Jewish faces that Celan believed had been effaced, first by Christian allegory, where the Lamentations of the Hebrew Prophet Jeremiah were assimilated, in Latin, into the Tenebrae service of the Catholic Holy Week; and then, as the murderous logic continued in the history of modern Europe, violently assimilated to the point of extermination by National Socialism.

Eruptions of the Ethical Baroque, which disrupt the serenity of art and haunt us: eruptions which reveal the face of Clorinda, in both Tasso's Jerusalem Delivered and Monteverdi's Combattimento di Tancredi e Clorinda; an eruption that reveals, to Rembrandt's Abraham, the face of his son Isaac and which thus interrupts what appeared to have been an imminent murder; an eruption which forces us to encounter, in disruptively sober prose, Shylock's Jewish eyes; and which, in Celan's arguably modern Baroque poem Tenebrae, interrupts — but too late, tragically-the profoundly enchanting pathos of Couperin's Leçons de ténèbres. 


\footnotetext{
' Gilles Deleuze, The Fold: Leibniz and the Baroque, trans. Tom Conley (Minneapolis: University of Minnesota Press, 1993); Mieke Bal, Quoting Caravaggio: Contemporary Art, Preposterous History (Chicago: University of Chicago Press, 1999); Walter Benjamin, The Origins of German Tragic Drama, trans. John Osborne (New York and London: Verso, 1998); Christine Buci-Glucksman, Baroque Reason: The Aesthetics of Modernity, trans. Patrick Camiller (London: Sage Publications, 1994); José Antonio Maravall, Culture of the Baroque: Analysis of a Historical Structure, trans. Terry Cochran (Minneapolis: University of Minnesota Press, 1986); Heinrich Wölfflin, Renaissance and Baroque, trans. Kathrin Simon (Ithaca: Cornell University Press, 1966); Robert Harbison, Reflections on Baroque (Chicago: University of Chicago Press, 2000); Andrea Battistini, II Barocco: Cultura, Miti, Immagini (Roma: Salerno Editrice, 2000); Leo Spitzer, "Le Récit de Théramène," Linguistics and Literary History: Essays in Stylistics (Princeton: Princeton University Press, pp. 87-134, 1948; René Wellek, "The Concept of the Baroque in Literary Scholarship," The Journal of Aesthetics and Art Criticism, Vol. 5, No. 2, (Dec., 1946), pp. 77-109. The critics who have most influenced my own conception of the Baroque are Wölfflin and Benjamin. To these I would add, perhaps idiosyncratically, Emmanuel Levinas, who has written provocatively of seventeenth-century literature in his early essay "Reality and its Shadow" (1948), trans. Alfonso Lingis, The Levinas Reader, ed. Seán Hand (Oxford: Blackwell, 1989; rpt. 1998), pp. 129-143. See also Levinas's essay “Don Quixote: Bewitchment and Hunger," God, Death, and Time, trans. Bettina Bergo (Stanford: Stanford University Press, 2000), pp. 167171; this chapter is a transcription of a lecture Levinas delivered at the Sorbonne on February 13, 1976. Levinas's own later prose, as he gestures towards the ethical in his book Otherwise than Being, or Beyond Essence (1974), has been described as "rather Baroque" (Simon Critchley and Robert Bernasconi, The Cambridge Companion to Levinas [Cambridge: Cambridge University Press, 2002], p. 18).

The present essay draws on some of my previously published work: "The Idea of Europe, Levinas, and Shakespeare's The Merchant of Venice," Engaging Europe: Rethinking a Changing Continent, eds. Evlyn Gould and George J. Sheridan (Lanham, Boulder, New York, Toronto, Oxford [UK]: Rowman \& Littlefield, 2005), pp. 63-78; and "War and the Hellenic Splendor of Knowing: Levinas, Euripides, Celan," Comparative Literature. Fall 2004. Vol. 56, pp. 347-6I; and "Justice, Injustice, and the Differentiation of the Monotheistic Worldview: Reflections on Genesis 18, 20, and 22," International Readings on_Theory, History and Philosophy of Culture, No. 19 (2004), pp. 20I-12. It also contains some material that is forthcoming in my book Other Others: Levinas/Literature/Transcultural Studies (SUNY Press).

${ }^{2}$ The Renaissance Philosophy of Man, p. 125.

${ }^{3}$ See Carl Schmitt, The Concept of the Political, trans. George Schwab (New Brunswick, NJ: Rutgers University Press, 1976), p. 26.

${ }^{4}$ Renaissance and Baroque, pp. 84-85.

${ }^{5}$ David Schulenberg, Music of the Baroque (New York and Oxford: Oxford University Press, 200 I), pp. 7576.

${ }^{6}$ Who is the subject of the verb mori? The sentence has no explicit subject, no noun or pronoun that would indicate the gender of the subject. Is the subject of mori Tancredi or Clorinda? Or both? For Tancredi, emotionally, and Clorinda, physically and literally, are both having near-death experiences ${ }^{77}$ Italian text cited from Monteverdi's Madrigali Guerrieri, et Amorosi (Venice, 1638), Madrigals Book VIII, ed. Gian Francesco Malipiero, with a preface and new literal translations of the texts by Stanley Appelbaum [New York: Dover, 1991], p. xxiv. The translation is by Ralph Nash, Jerusalem Delivered (Detroit: Wayne State University Press, 1987), p. 269.

${ }^{8}$ Monteverdi: Music in Transition, trans. from the German by Anne Smith (Oxford: Clarendon Press, 1991), p. 195.

${ }^{9}$ From Monteverdi's introductory note to the manuscript version of the Combattimento, published as one of his Madrigali Guerrieri, et Amorosi, Madrigals Book VIII, ed. Malipiero, pp. xvii and I44.

${ }^{10}$ Monteverdi's Tonal Language (New York: Schirmer Books, 1992), pp. 240-24I.

"Epic and Empire: Politics and Generic Form from Virgil to Milton (Princeton: Princeton University Press, 1993), p. 246.

${ }^{12}$ For Levinas's discussion of the "third party," see Otherwise than Being Or Beyond Essence, translated by Alphonso Lingis (Pittsburgh: Duquesne University Press, 1998), p. 16; Autrement qu'être ou au-delà de l'essence (Martinus Nijhoff: The Hague, 1974), p. 33. On the "third party" ("le tiers") in Levinas, see Robert Bernasconi, "The Third Party: Levinas on the Intersection of the Ethical and the Political," Journal
} 
of the British Society for Phenomenology, 1999, 30(I), Pp. 76-87. See also Howard Caygill, Levinas and the Political (London and New York: Routledge, 2002).

${ }^{13}$ Otherwise than Being, p. 64; Autrement qu'être, p. 105.

${ }^{14}$ Otherwise than Being, p. 197, n. 25. The French reads: "le langage théologique détruit la situation religieuse de la transcendance.... Le langage sur Dieu sonne faux ou se fait mythique, c'est-à-dire ne peut jamais être pris à la lettre" (Autrement qu'être, p. 192, n. I).

${ }^{15}$ Walter Benjamin: Selected Writings, 4 vols., (Cambridge, Mass. and London: Harvard University Press, 1996-2003), Vol. I: 1913-1926 (Cambridge Mass. and London: Harvard University Press, 1996), eds. Marcus Bullock and Michael W. Jennings, p. 250.

${ }^{16}$ Fragments of Redemption: Benjamin, Scholem, and Levinas (Bloomington and Indianapolis: Indiana University Press, 1991), p. 128.

${ }^{17}$ The Origin of German Tragic Drama, introduced by George Steiner, translated by John Osborne (New York: Verso 1998; rpt. 2003), p. 183.

${ }_{18}^{18}$ Benjamin: Selected Writings, Vol. 4: 1938-1940 (Cambridge, Mass. and London: Harvard University Press, 2003), trans. Edmund Jephcott and Others, eds. Howard Eiland and Michael W. Jennings, p. 397.

${ }^{19}$ Trans. Everett Fox, The Five Books of Moses: Genesis, Exodus, Leviticus, Numbers, Deuteronomy (New York: Schocken Books, 1983; rpt. 1995), pp. 94-95. Where I do not cite a translator of the Hebrew text, the translation is my own.

${ }^{20}$ The "baroque" nature of Rembrandt's painting consists, in large part, in its debt to what John Rupert Martin refers to as "the naturalistic vision of the Baroque" (Baroque [New York: Harper \& Row, 1977], p. 13), especially as achieved by Caravaggio. While baroque painters were certainly not averse to allegorical representation, they tended to stress the dramatic nature of scenes from the Hebrew bible rather than their mere typological significance. For the indirect influence of Caravaggio via Lastman on Rembrandt's 1635 painting of The Sacrifice of Isaac, see J. Bruyn, "Rembrandt and the Italian Baroque," Simiolus 4 (1970), 28-48, esp. Pp. 39-40. Rembrandt appears to have been inspired by Lastman's depiction of Abraham's looking directly at the face of the angel. This dramatic gesture "in turn seems to be based on two famous paintings of Caravaggio which Lastman may have seen in Italy between 1603 and 1606: St. Matthew and the Angel and The Sacrifice of Isaac" (Astrid Tümpel and Peter Schatborn, Pieter Lastman: The Man Who Taught Rembrandt (Amsterdam: Waanders Uitgevers, Zwolle, 1991), p. 65.

${ }^{21}$ Simon Schama, Rembrandt's Eyes (Knopf: New York, 1999), p. 605.

${ }^{22}$ For "durative, non-specific" commands, the word for "not" that precedes the imperative proper would be 10 '- rather than the two instances of 'al- that we find in this passage. See Thomas O. Lambdin, Introduction to Hebrew (Upper Saddle River, New Jersey: Prenctice Hall, 197I), p. II 4.

${ }^{23}$ In Caravaggio's painting (I60I-2) of The Sacrifice of Isaac (in the Uffizi Gallery, Florence), Abraham has forcibly placed Isaac's body prone onto the altar of sacrifice and he is trying to hold Isaac's terrified face down when the angel appears and stays Abraham's hand.

${ }^{24}$ See Khaleel Mohammed, "Probing the Identity of the Sacrificial Son in the Qur'an," Journal of Religion and Culture, Vol. I3 (1999), pp. I25-132. Professor Mohammed argues that it is thoroughly misleading to assume that "the Islamic view" (p. I25) holds Ishmael to be the intended offering. Indeed, according to Professor Mohammed, "al-Tabari (dc. 310/923), arguably Islam's most famous exegete, along with several others viewed Isaac as the sacrificial son" (ibid.)

25 "Abraham, the Friend of the Merciful," 305, cited from The History of al-Tabari, Vol. II, Prophets and Patriarchs, translated and annotated by William M. Brinner [Albany: State University of New York Press, 1987], p. 93.

${ }^{26}$ See e.g. Levinas, "Ethics and Spirit," Difficult Freedom: Essays on Judaism, trans. Seán Hand (Baltimore: The Johns Hopkins University Press, 1990), esp. Pp. 7-10.

${ }^{27}$ Rembrandt's Eyes, p. 410.

${ }^{28}$ See Jeffrey Stolle, "Levinas and the Akedah: An Alternative to Kierkegaard," Philosophy Today (Summer 200I): 132-43. Max Van Manen argues that in their paintings discussed above, "both Caravaggio and Rembrandt anticipate Levinas in their understanding of the significance of the face as the ethical experience of responsibility for the other, and in particular for one's child" ("Care-As-Worry, or 'Don't Worry Be Happy,"'- Qualitative Health Research: An International, Interdisciplinary Journal, Sage Publications, Vol. 12, No. 2, February 2002, p. 274). See also Claire Elise Katz, Levinas, Judaism, and the Feminine (Bloomington \& Indianopolis: Indiana University Press, 2003), who argues that "it is when Abraham sees Isaac's face that he shifts his responsibility from God to Isaac, his son" (p. II8). In his essay "Critique of 
Violence," cited earlier, Walter Benjamin speculates on the distinction between what he calls mythic and divine violence in ways that are suggestive for my interpretation of the Akedah which, in my view, narrates a shift from what Levinas calls "le sacré au saint" (the sacred to the holy). "Mythic violence," Benjamin writes, "is bloody power over mere life for its own sake; divine violence [which Benjamin associates with the God of the Hebrew Bible] is pure power over all life for the sake of the living" (Walter Benjamin: Selected Writings, Vol. I [1913-1926], eds. Bullock and Jennings, p. 250). For Levinas's distinction between the "le sacré" (the sacred) and "le saint" (the holy), see Emmanuel Levinas, Du sacré au saint: cinq lectures talmudiques (Paris: Les Editions de Minuit, 1977).

${ }^{29}$ Emmanuel Levinas, Ethics and Infinity: Conversations with Philippe Nemo, trans. Richard A. Cohen (Pittsburgh: Duquesne University Press, 1998), p. 87. Ethique et infini was published in French in 1982. For Jacques Derrida's reflections on the Aqedah, and on Kierkegaard's and Levinas's readings of this text, see Donner la mort in L'éthique du don (Paris: Métalié-Tansition, 1992), translated into English by David Wills as The Gift of Death (Chicago: University of Chicago Press, 1995); see especially Chapter Three. For stimulating reflections on Kierkegaard's, Levinas's, and Derrida's reflections on the Aqedah, see Hent de Vries, Religion and Violence: Philosophical Perspectives from Kant to Derrida (Baltimore and London: The Johns Hopkins University Press, 2002), esp. Chapter Two ("Violence and Testimony: Kierkegaardian Meditations"), pp. 123-210.

${ }^{30}$ See e.g. Levinas, "The Trace of the Other," trans. Alfonso Lingis, in Deconstruction in Context: Literature and Philosophy, ed. Mark C. Taylor (Chicago: The University of Chicago Press, 1986), p. 3I, and "“'A ManGod?", Entre Nous: Thinking-of-The-Other, trans. Michael B. Smith and Barbar Harshav (New York: Columbia University Press, 1998), p. 58.

${ }^{31}$ Ibid., p. 4II. In the Munich version of this painting (also 1635; attributed to Rembrandt and another artist who worked in Rembrandt's studio), Abraham's face appears to be even more stunned, and the angel's intervention less gentle. Here the angel appears to be coming towards the viewer, and his body twists more emphatically, more urgently towards Abraham in order to stay the patriarch's hand.

32 As Howard Hibbard comments, "Caravaggio may simply have been commissioned to paint this familiar subject from Genesis, but his interpretation seems unnecesarily cruel. Poor Isaac has become little more than an animal sacrifice, although his horror is plainly evident: Caravaggio was fascinated by the idea of a head cut off or a throat cut" (Caravaggio [New York: Harper \& Row, 183; rpt. 1985), p. 166).

${ }^{33}$ Origin of German Tragic Drama, p. 228.

34 Ibid.

${ }^{35}$ All quotations from this play will be cited from The Complete Works of William Shakespeare, ed. David Bevington, third edition (New York: Longman, 1997).

${ }^{36}$ Levinas Reader, ed. Seán Hand (Oxford and Cambridge: Blackwell),p. I 43

37 Totality and Infinity: An Essay on Extriority, trans. Alphonso Lingis (Pittsburgh, PA: Duquesne University Press), pp. 202-203.

${ }^{38}$ See, for example, Buci-Glucksmann's Baroque Reason: The Aesthetics of Modernity (1984) and Mieke Bal's Quoting Caravaggio (1999).

${ }^{39}$ The English is quoted here from the King James version, the Latin from the Vulgate.

40 The German text and English translations of Celan's poetry will be cited from Selected Poems and Prose of Paul Celan, translated by John Felstiner (New York: Norton, 2001), Pp. 102-103. In the case of Tenebrae, I have taken the liberty of slightly modifying Felstiner's translation.

${ }^{41}$ As in the Buber/Rosenzweig translation, which Celan knew and studied. See Die Fünf Bücher der Weisung/Fünf Bücher des Moses (Köln and Olten: Jakob Hegner, 1968), p. I I: "Gott sprach: / Machen wir den Menschen in unserem Bild nach unserem Gleichnis!/... Gott schuf den Menschen in seinem Bilde,/ im Bilde Gottes schuf er ihn... . [God spoke: We have made man in our image, after our likeness!/... God made man in His image, in the image of God He made him]."

${ }^{42}$ As cited by Jerry Glenn, Paul Celan (New York: Twayne, 1973), p. 99. 